WCH-544

Rev. 0

River Corridor Closure Contract

\title{
Environmental Restoration Disposal Facility Lessons Learned
}

July 2012

For Public Release

\section{Washington Closure Hanford}

Prepared for the U.S. Department of Energy, Richland Operations Office Office of Assistant Manager for River Corridor 
TRADEMARK DISCLAIMER

Reference herein to any specific commercial product, process, or service by trade name, trademark, manufacturer, or otherwise, does not necessarily constitute or imply its endorsement, recommendation, or favoring by the United States Government or any agency thereof or its contractors or subcontractors.

This report has been reproduced from the best available copy.

Printed in the United States of America 
DOCUMENT $|12| 2012^{a} 8$

WCH-544

Rev. 0

STANDARD APPROVAL PAGE

Title: $\quad$ Environmental Restoration Disposal Facility Lessons Learned

Author Name: R. Caulfield

Approval: $\quad$ R. Caulfield, ERDF Operations Manager

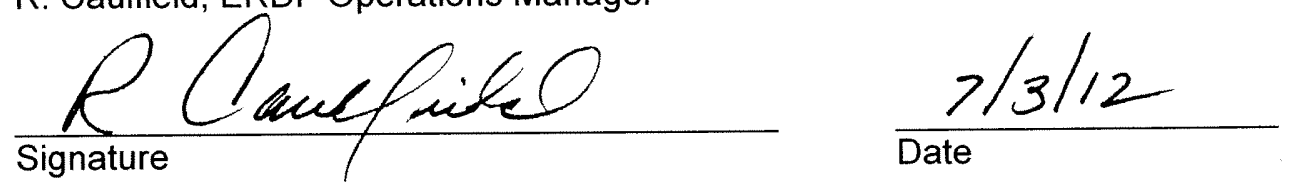

The approval signature on this page indicates that this document has been authorized for information release to the public through appropriate channels. No other forms or signatures are required to document this information release. 
WCH-544

Rev. 0

\section{River Corridor Closure Contract}

\section{Environmental Restoration Disposal Facility Lessons Learned}

July 2012

Authors:

R. Caulfield

For Public Release 


\section{TABLE OF CONTENTS}

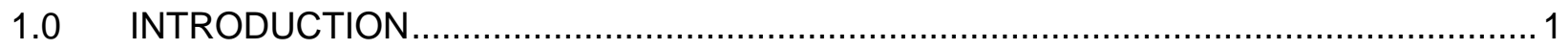

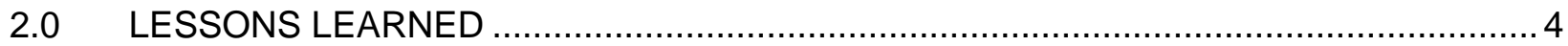

2.1 CONSTRUCTION OF "SUPER" CELLS 9 AND 10.................................... 4

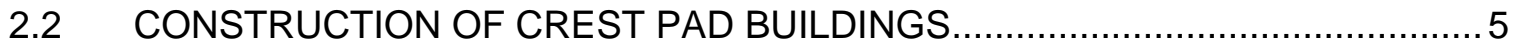

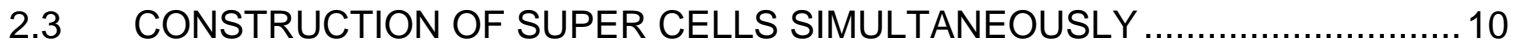

2.4 CONSTRUCTION OF ERDF MAINTENANCE FACILITIES BY ONE SUBCONTRACTOR ........................................................................... 10

2.5 USING "BEST VALUE" SELECTION PROCESS TO PURCHASE NEW OR

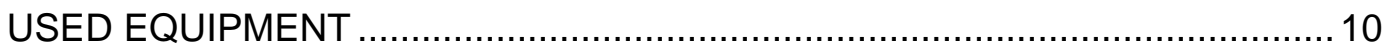

2.6 FAILING TO USE "BEST VALUE" SELECTION PROCESS .......................... 11

\section{FIGURES}

1. Aerial View of ERDF. .

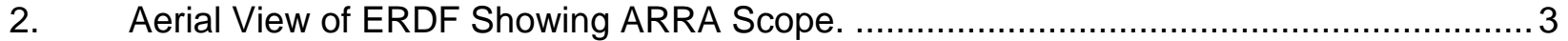

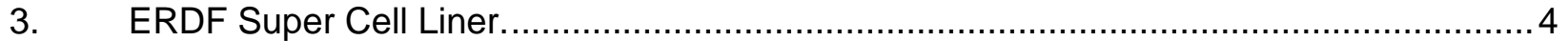

4. Each Super Cell Required Only One Sump, Saving on Cost and Labor........................6

5. WCH Replaced a 12-in. Layer of Drainage Gravel with a Geocomposite Layer, Creating Space and Reducing Construction Cost.......................................... 7

6. WCH Installs Leachate Transmission Pipes from the Super Cell 9

Sump to it is Associated Crest Pad Building............................................................. 8

7. $\quad$ Each Super Cell Requires Only One Crest Pad Building ........................................ 9

8. WCH Constructed Super Cells 9 and 10 Simultaneously, Saving Time and Construction Costs................................................................. 12

9. ERDF's New Truck Maintenance Facility........................................................... 13

10. Using Only One Primary Subcontractor to construct the New Maintenance Facilities Resulted in Time and Cost Savings........................................................................ 13

11. WCH Used the "Best Value" Selection Process to Purchase 20 New Waste Transport Trucks.

12. ERDF Received 15 New 25-Ton-Capacity Waste Containers Purchased Using the "Best Value" Selection Process.

13. Washington Closure Used the "Best Value" Selection Process to Purchase Two D-9 Bulldozers. 


\subsection{INTRODUCTION}

Washington Closure Hanford (WCH) manages the $\$ 2.3$ billion River Corridor Closure Project for the U.S. Department of Energy (DOE). The River Corridor is a 220- $\mathrm{mi}^{2}$ section of land located along the Columbia River on the $586-\mathrm{mi}^{2}$ Hanford Site in southeastern Washington State. $\mathrm{WCH}$ is responsible for cleaning up 555 waste sites, demolishing 329 contaminated buildings, placing two plutonium production reactors and one nuclear facility in interim safe storage, and operating Hanford's Environmental Restoration Disposal Facility (ERDF) (Figure 1).

ERDF is regulated by the U.S. Environmental Protection Agency (EPA) and began operations in 1996 to provide transportation, treatment, and waste disposal services. The facility accepts lowlevel, radioactive, hazardous, and mixed wastes generated during Hanford cleanup activities.

The majority of waste ERDF receives comes from the River Corridor, which is home to Hanford's nine plutonium production reactors. The waste consists mainly of contaminated soil, building debris, and other hazardous materials such as mercury, asbestos, beryllium, chromium and lead. In recent years, other Hanford contractors, including Hanford's Central Plateau Remediation contractor, have been delivering increasing amounts of waste to ERDF for disposal.

In 2011, WCH completed a $\$ 100$ million expansion and upgrade of ERDF funded by the American Recovery and Reinvestment Act (ARRA). The money spent at ERDF was part of $\$ 233.6$ million designated to WCH by DOE for use on "shovel ready" projects. The goal of the ERDF expansion project was to increase the facility's capacity to accommodate escalating waste volumes generated by ARRA cleanup activities and also to support future operations at the facility (Figure 2).

The ERDF expansion project included:

- Two large disposal areas called "super" cells

- Two new leachate storage tanks to replace the facility's two original tanks

- Three maintenance facilities and an operations center

- Equipment for disposal operations

- Upgrades of site roads

- Expansion of container transfer area

- Onsite batch plant. 


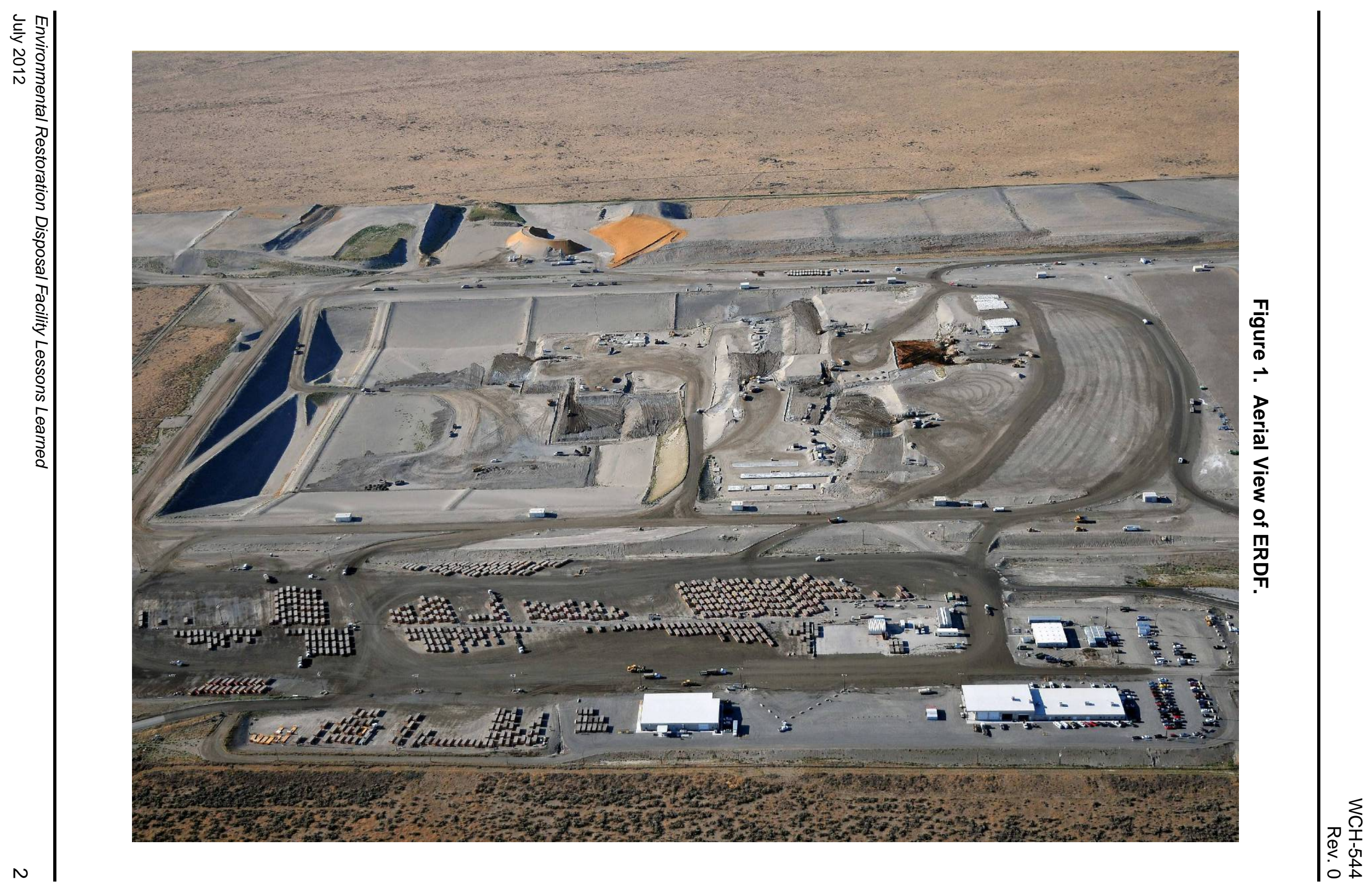




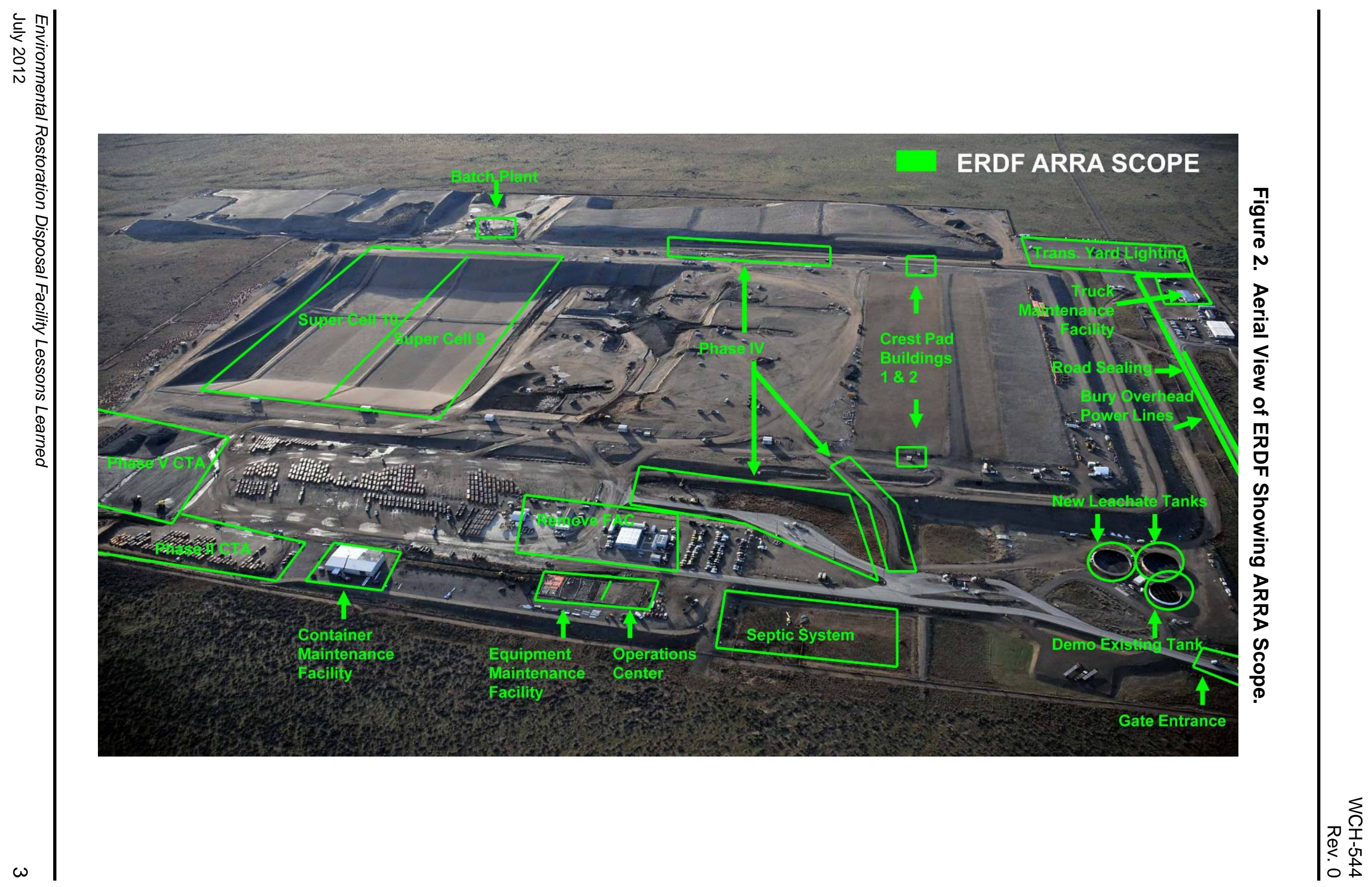




\subsection{LESSONS LEARNED}

The purpose of lessons learned is to identify insight gained during a project - successes or failures - that can be applied on future projects. Lessons learned can contribute to the overall success of a project by building on approaches that have worked well and avoiding previous mistakes. Below are examples of lessons learned during ERDF's ARRA-funded expansion project,

\subsection{CONSTRUCTION OF "SUPER" CELLS 9 AND 10}

ERDF is made up of disposal areas called cells. Each cell is constructed with bottom and side liners consisting of multiple layers of natural and man-made materials that form an impermeable barrier (Figure 3), along with a system to catch liquid waste that drains through the waste materials.

A super cell is equivalent in size to a pair of existing cells (500 ft wide, 1,000 ft long, and $70 \mathrm{ft}$ deep with a capacity of 2.8 million tons of waste). Previously, each pair of cells required two systems to collect leachate. A super cell is more cost-efficient and easier to construct because it accomplishes leachate collection with a single system, resulting in the need for fewer pumps, motors, crest pad buildings, valves, manholes, and other pieces of equipment. Overall, the design enhancements and decrease in labor resulted in a cost reduction of $\$ 1,450,000$ per super cell.

Figure 3. ERDF Super Cell Liner.

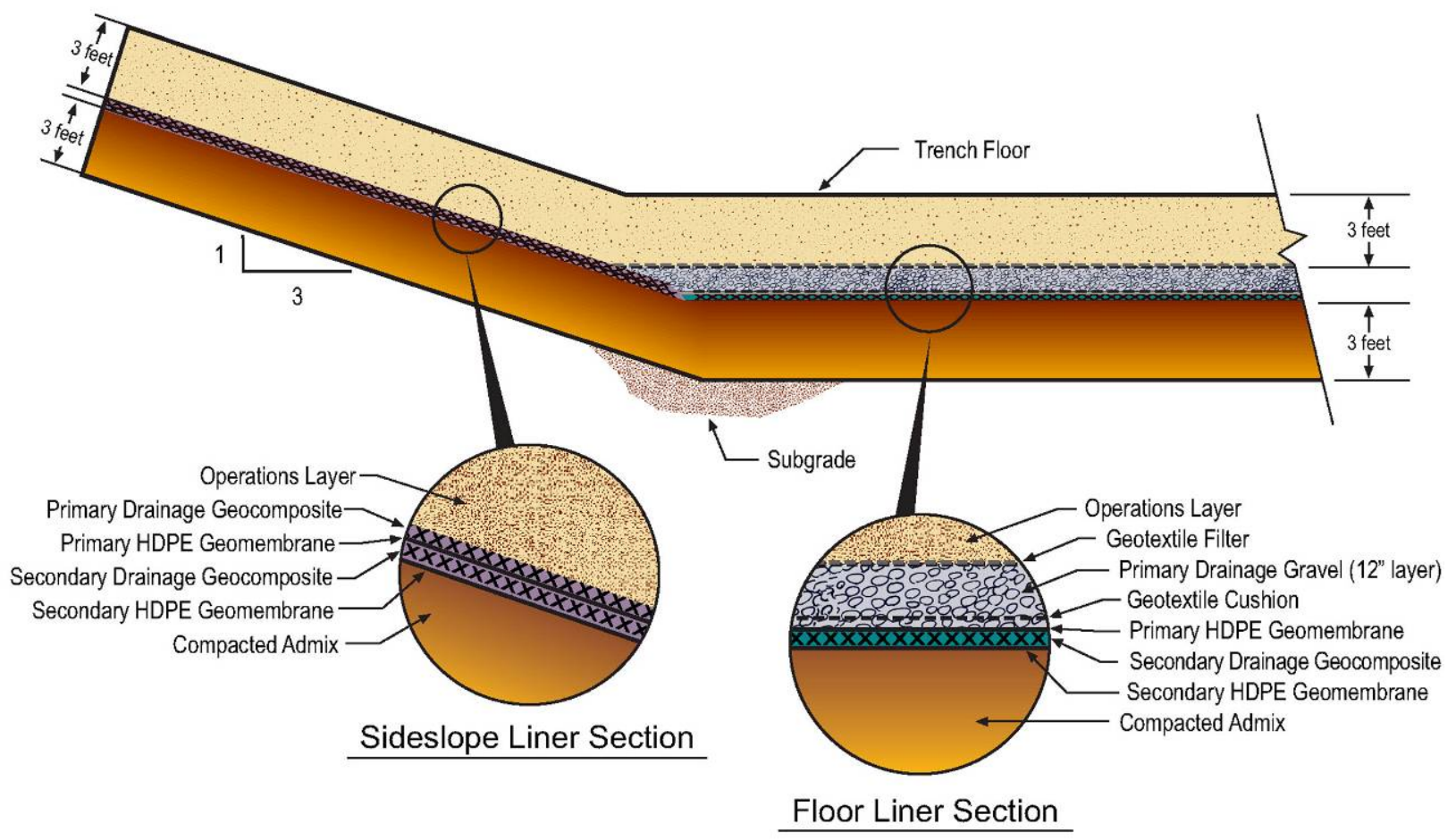


The four basic design enhancements of a super cell are:

- Eliminating one of two sumps (Figure 4), one of two crest pads, $500 \mathrm{ft}$ of leachate transmission pipe, $500 \mathrm{ft}$ of buried electrical power supply, and a lysimeter $(\$ 715,000$ cost reduction). The single sump simplifies construction and reduces operations and maintenance costs for additional pumps and monitoring equipment. Eliminating a sump also increases waste capacity by eliminating sub-grade crest between cells. A reduction in the number of liner seams also reduces the potential for leakage.

- Replacing the 12-in. secondary drainage gravel layer in the liner system with geocomposite material (\$610,000 cost reduction) (Figure 5). The advanced liner system consists of a 3-ft layer of admix, two layers of high-density polyethylene (HDPE), a 1-ft layer of gravel with a 12-in. perforated drainage pipe, a geocomposite layer, and two geotextile layers covered with a 3-ft protective soil layer. Replacing the secondary drainage gravel layer with geocomposite increases waste capacity by 12 in. and reduces the potential for liner system damage caused by eliminating the use of heavy equipment for installation. Installation time is also reduced.

- Replacing a network of leachate collection pipes with a single leachate collection pipe (\$105,000 cost reduction). In place of a complex network of 4- and 6-in. primary collection pipes, a single 12-in. collection pipe runs down the entire flow line of the super cell. The single collection pipe simplifies and accelerates installation, and also reduces the potential of damage to the liner system (Figure 6).

- Replacing the sealed double-ring infiltrometer (SDRI) test with Boutwell test method on admix test pad (\$20,000 cost reduction). Both tests are used to measure in situ hydraulic conductivity of the admix layer, but the Boutwell test method provides measurements over several areas of the test pad, whereas, the SDRI test provides measurements over only one area of the test pad. The Boutwell test method is more cost efficient and take less time to perform -2 weeks compared to 90 days for the SDRI test.

\subsection{CONSTRUCTION OF CREST PAD BUILDINGS}

A crest pad building houses the valves and electronics associated with the leachate pumping system for a cell. Each cell or super cell has an associated crest pad building. Using feedback of the contractor from previous cell construction, WCH moved the crest pad building for each super cell $10 \mathrm{ft}$ back from the cells anchor trench, where the liner system of the cell is secured or "anchored." This allowed the crest pad buildings to be constructed during liner installation. During the construction of cells 1 through 8, the crest pad buildings were built on top of the anchor trenches (Figure 7). 


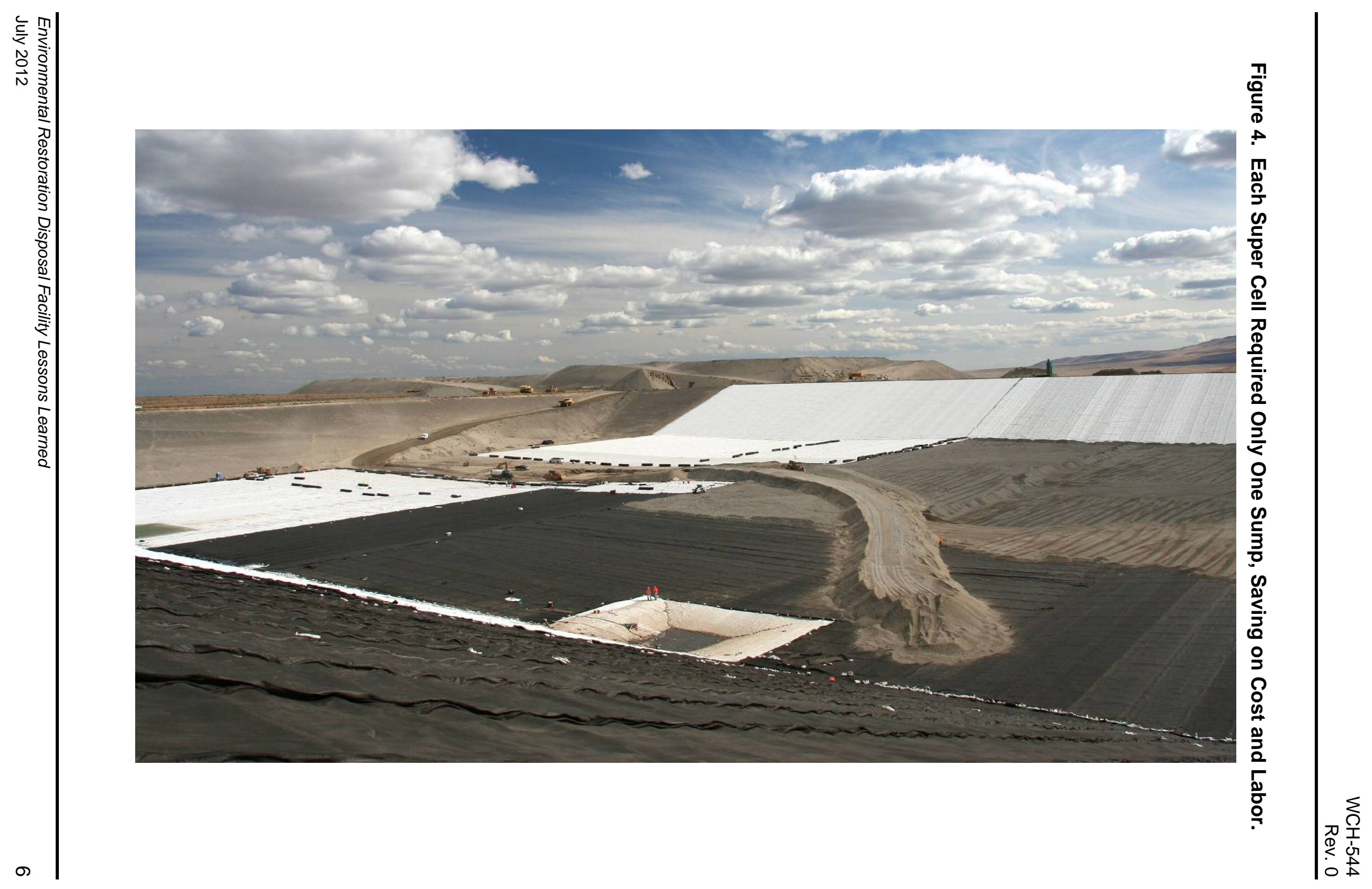


Figure 5. WCH Replaced a 12-in. Layer of Drainage Gravel with a Geocomposite Layer, Creating Space and Reducing Construction Cost.

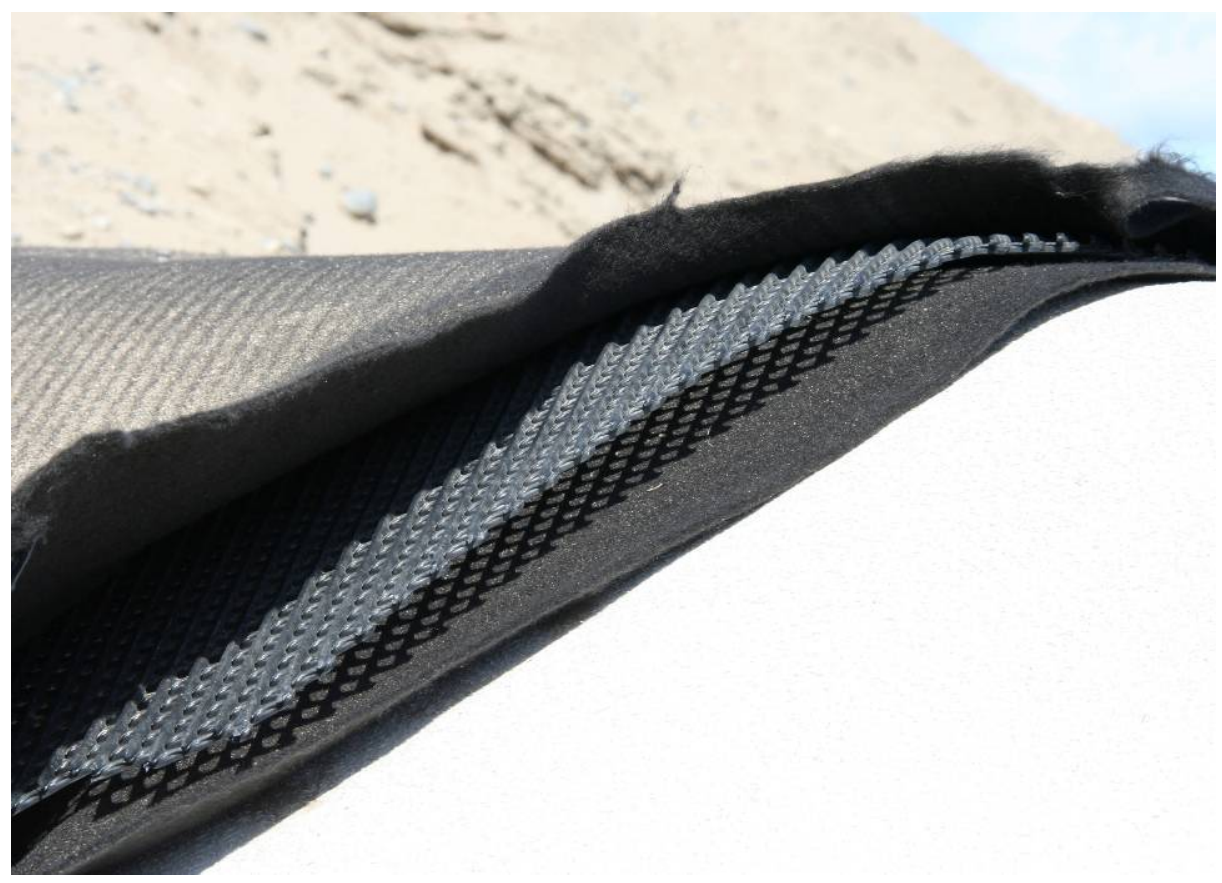


Figure 6. WCH Installs Leachate Transmission Pipes from the Super Cell 9 Sump to it is Associated Crest Pad Building.

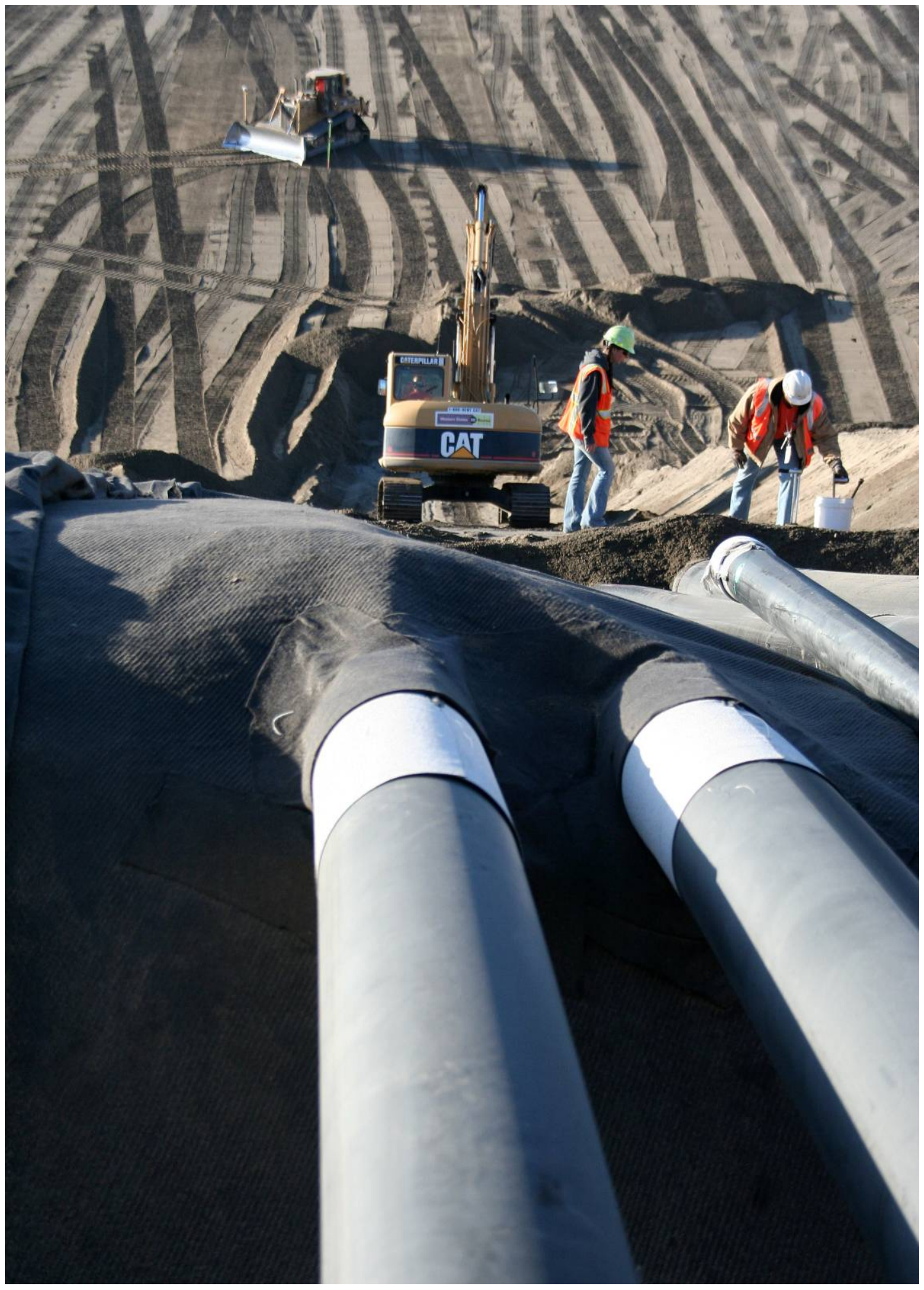




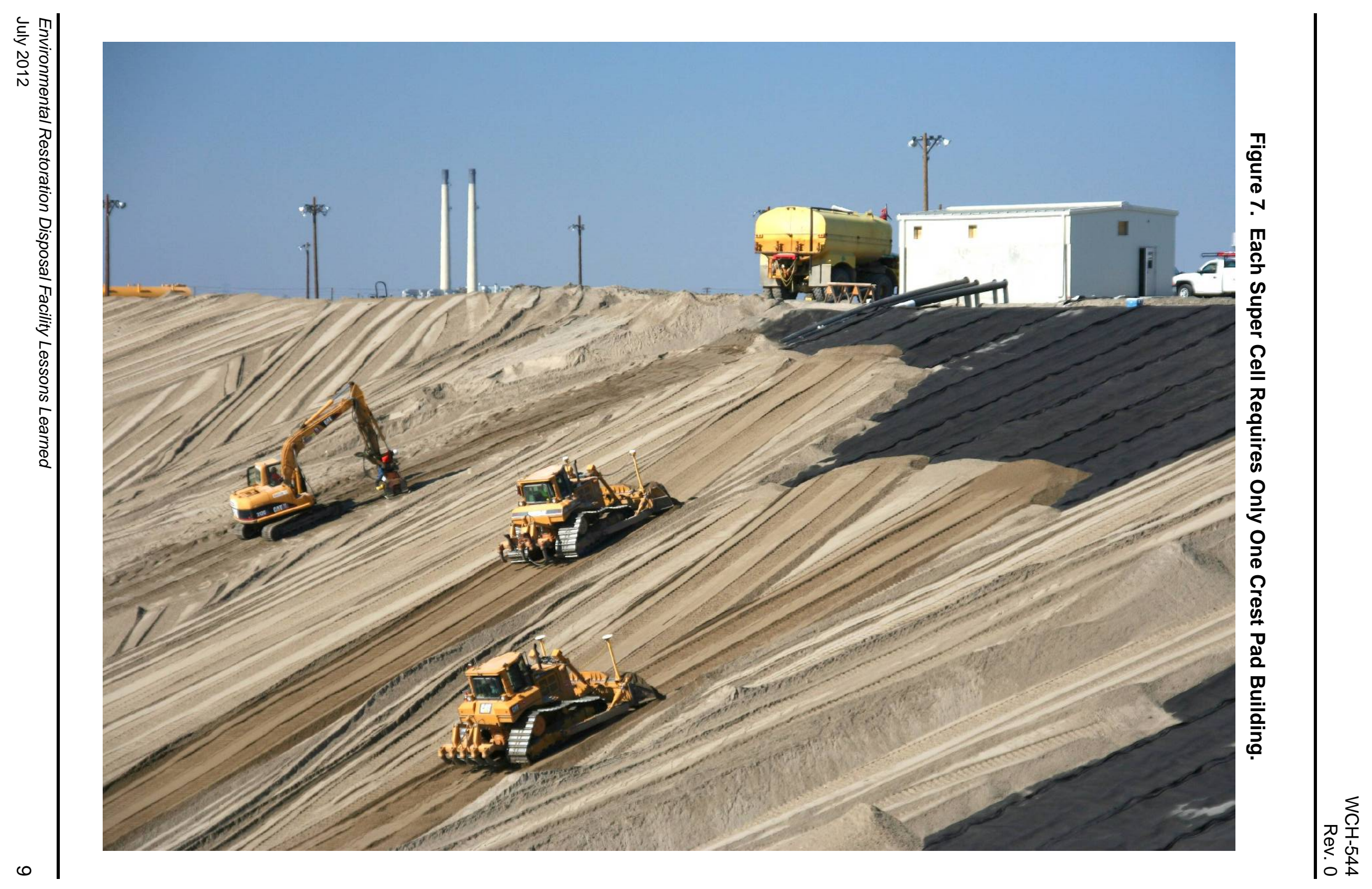




\subsection{CONSTRUCTION OF SUPER CELLS SIMULTANEOUSLY}

WCH began excavating super cell 10 while installing the liner system for super cell 9 (Figure 8). Constructing the super cells at the same time led to several cost savings and efficiencies. Among them were the following:

- $\quad$ Simplified the procurement process

- Reduced time to review submittals

- Eliminated the need to mobilize and demobilize a second time

- Eliminated the need for an additional access ramp into the construction area

- Improved communication.

WCH completed construction of the super cells several months ahead of schedule and well under budget. Super cell 9 cost $\$ 24.7$ million, about $\$ 7.1$ million under budget. Super cell 10 cost $\$ 26.8$ million, about $\$ 10.9$ million under budget, and included upgrades to the leachate transmission pipe and construction of two new leachate holding tanks.

\subsection{CONSTRUCTION OF ERDF MAINTENANCE FACILITIES BY ONE SUBCONTRACTOR}

WCH completed construction of three maintenance facilities and an operations center to support waste disposal operations throughout the facility's existence. The maintenance facilities are for waste transport trucks (Figure 9), waste containers, and heavy equipment. The operations center alleviated overcrowding and provides ERDF staff space to conduct plan-of-the-day meetings. $\mathrm{WCH}$ awarded construction of the facilities to one prime subcontractor. Combining all construction and working with only one subcontractor led to cost savings and efficiencies (Figure 10). Among them were the following:

- Simplified the procurement process

- Simplified the training process

- Reduced time to review submittals

- All design and construction work under one subcontractor

- Improved communication.

\subsection{USING "BEST VALUE" SELECTION PROCESS TO PURCHASE NEW OR USED EQUIPMENT}

WCH used the "Best Value" selection process to purchase new or used equipment that allows the Waste Operations team to handle, transport, and dispose of waste in a more safe and efficient manner (Figures 11, 12, 13). The process was used to purchase:

- 20 shuttle trucks

- 4 bulldozers

- 2 mixer trucks

- 2 water trucks

- 2 manlifts

- 1 front-end loader

- 1 pumper truck 
- 1 fuel truck

- 1 large dump truck

- 50-ton forklift

- 150 waste containers.

During the "Best Value" selection process, WCH compared sources of goods and services and decided which one had the greatest potential for successful performance. The process reduced the need for WCH resources, which can be applied elsewhere, and minimized the uncertainty and risk surrounding critical purchases. The process is based on evaluation criteria where price is not the overriding factor. Other criteria used were:

- Meeting all specifications

- Model year of the unit

- Hours on the unit

- Warranty

- Delivery schedule

- Other options.

\subsection{FAILING TO USE "BEST VALUE" SELECTION PROCESS}

WCH failed to use the "Best Value" selection process when awarding a subcontract to perform design work for a new septic system to support the addition of ERDF's new maintenance buildings. The subcontract was awarded based on low bid to a contractor meeting minimum qualifications and experience. This resulted in $\mathrm{WCH}$ awarding the subcontract to a company with very little prior experience working on a government project, resulting in cost and schedule overruns. 


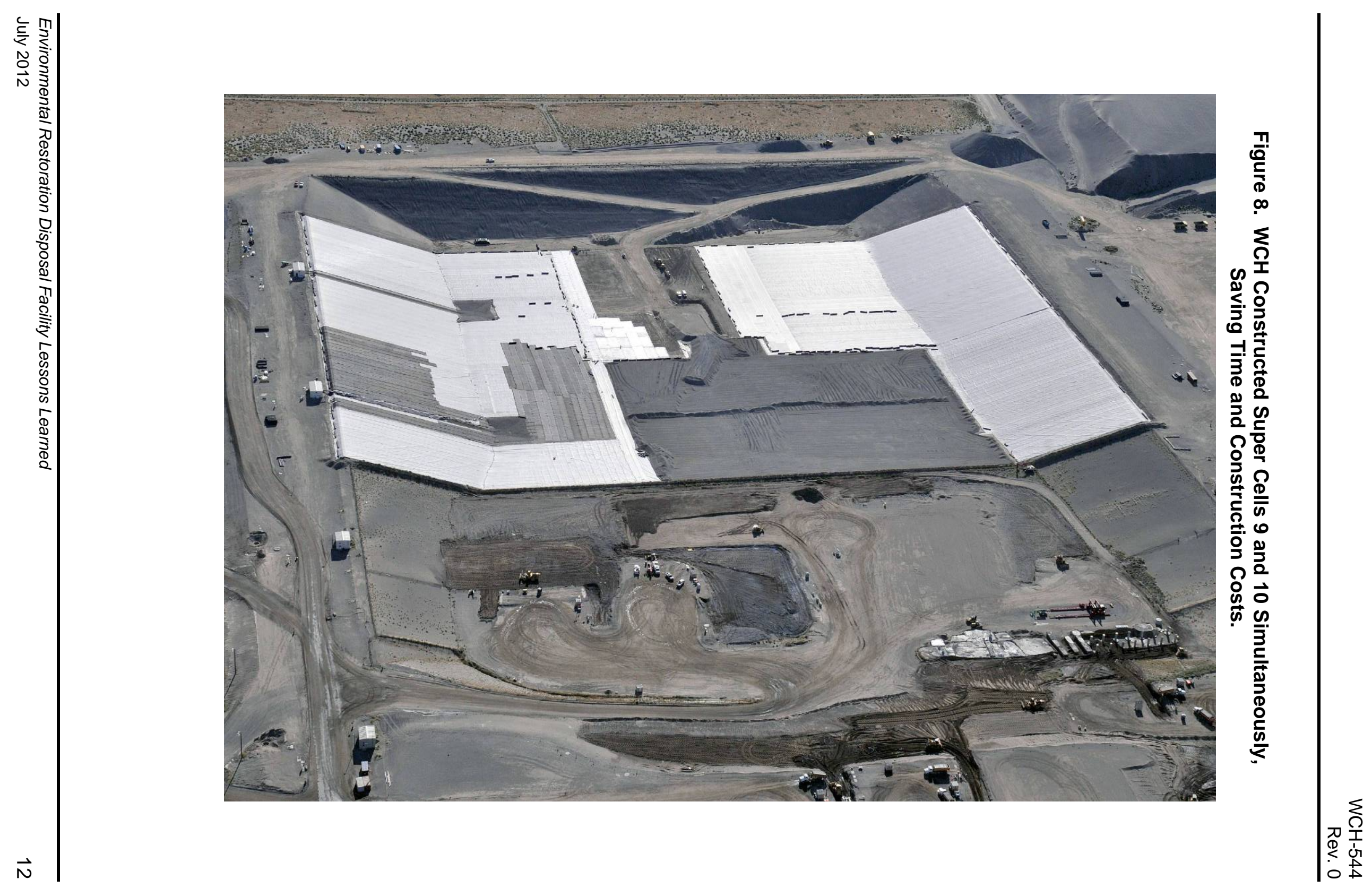


Figure 9. ERDF's New Truck Maintenance Facility.

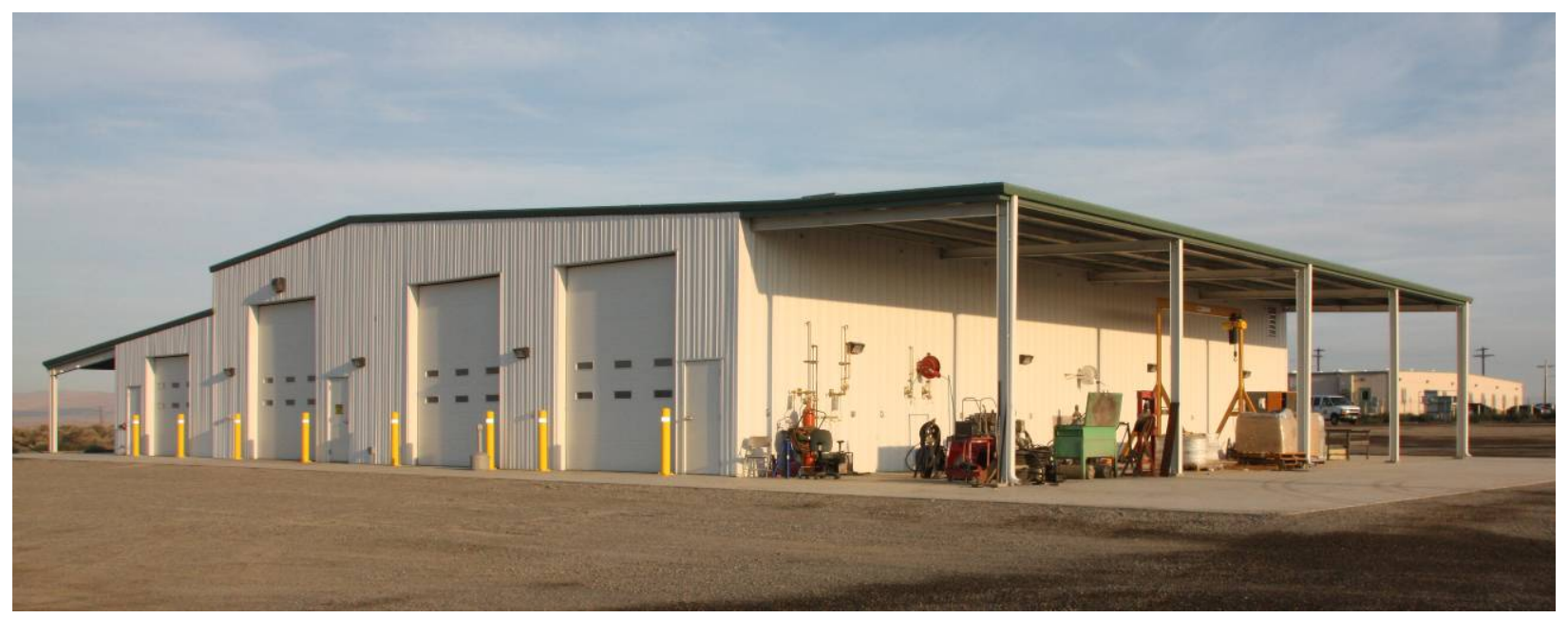

Figure 10. Using Only One Primary Subcontractor to construct the New Maintenance Facilities Resulted in Time and Cost Savings.

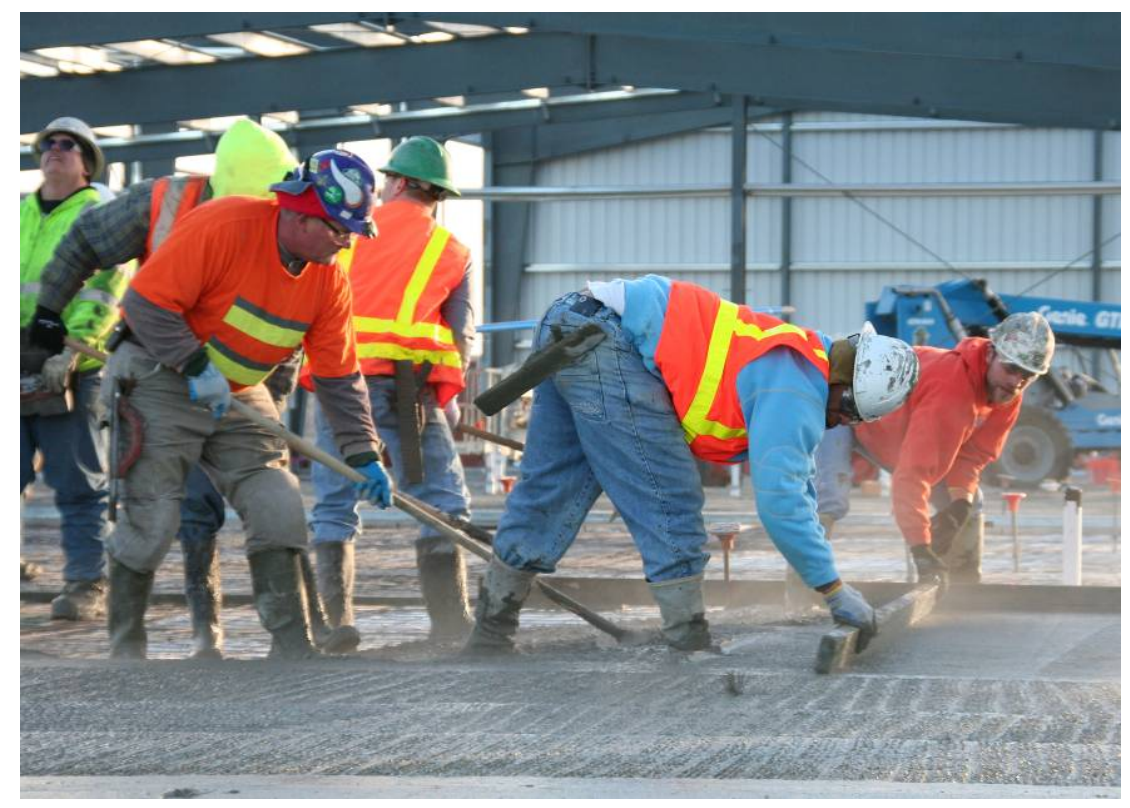


Figure 11. WCH Used the "Best Value" Selection Process to Purchase 20 New Waste Transport Trucks.

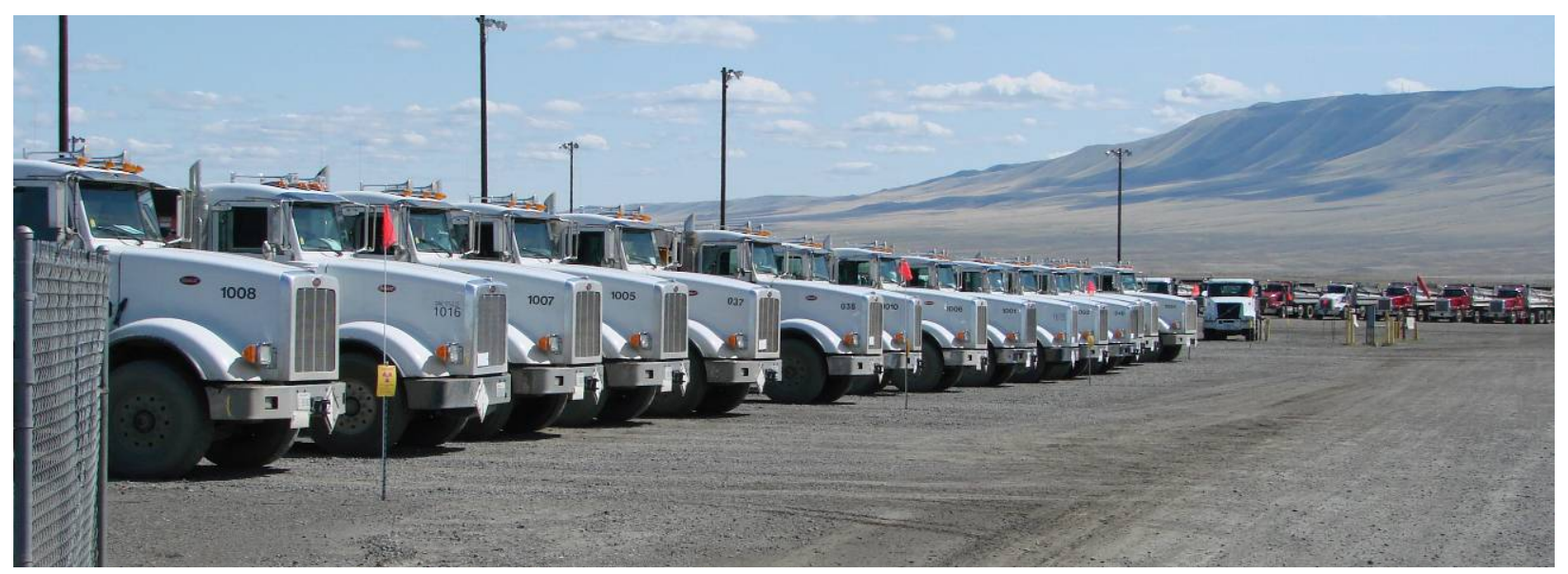

Figure 12. ERDF Received 15 New 25-Ton-Capacity Waste Containers Purchased Using the "Best Value" Selection Process.

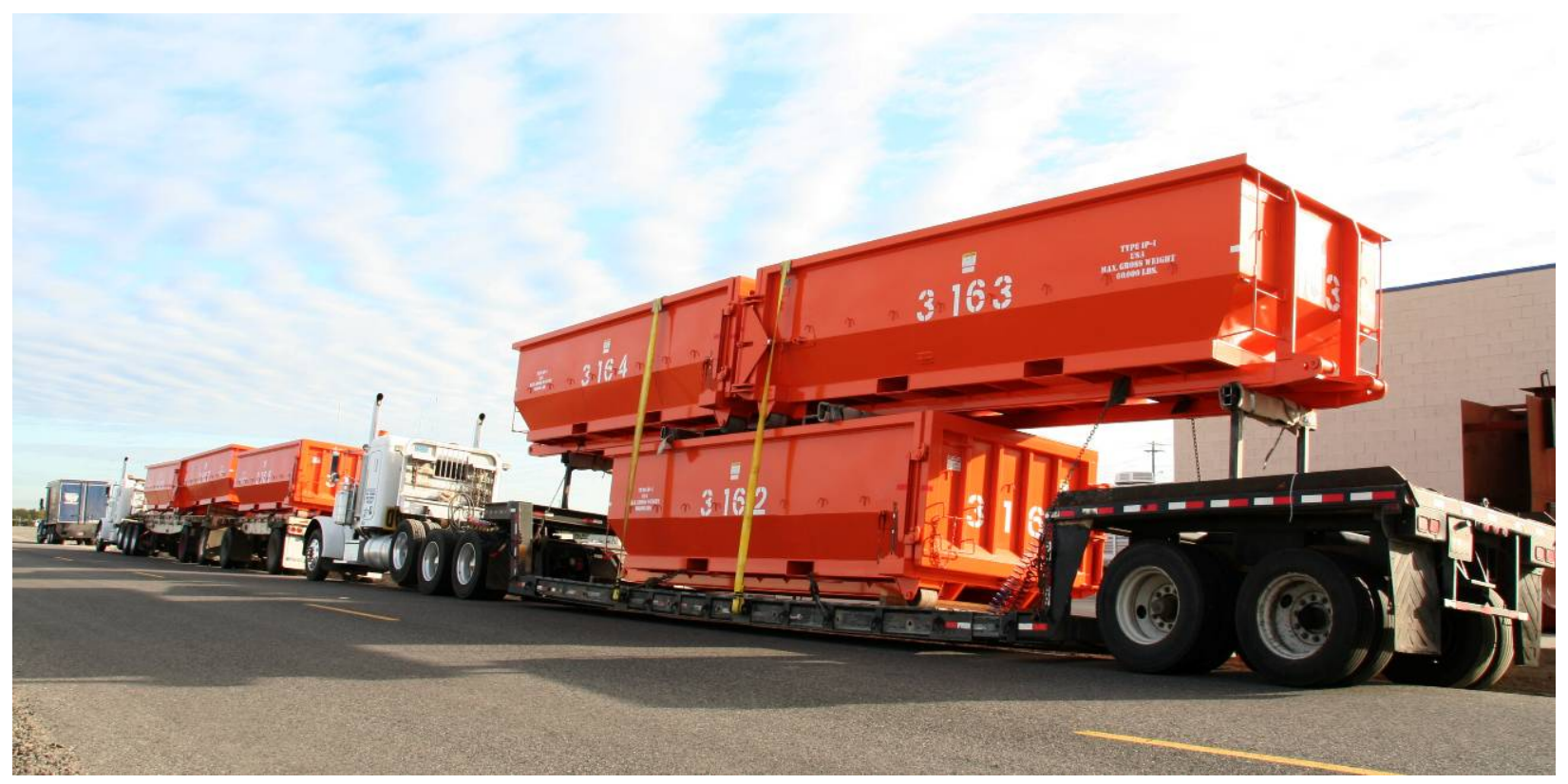


Figure 13. Washington Closure Used the "Best Value" Selection Process to Purchase Two D-9 Bulldozers.

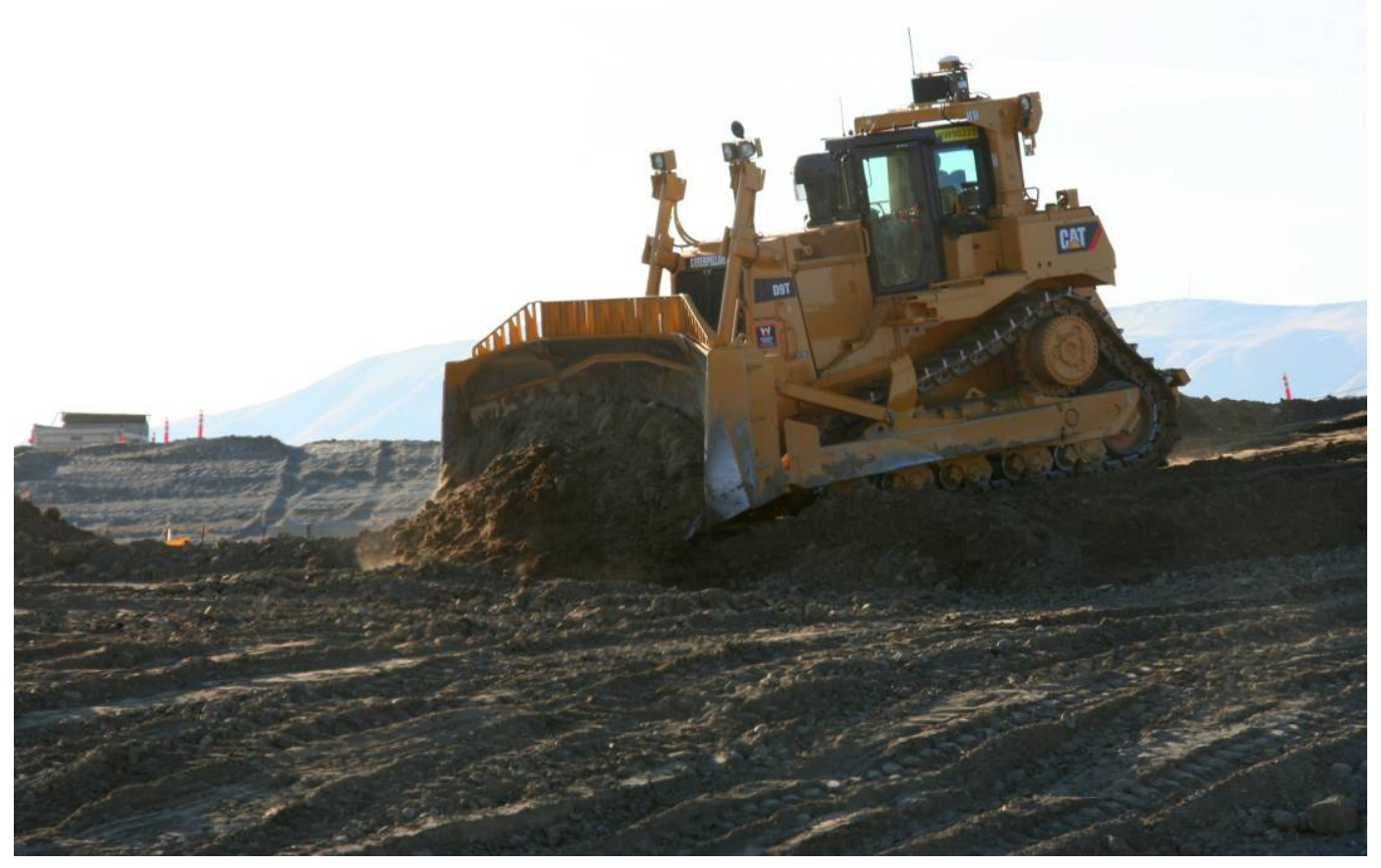




\section{DISTRIBUTION}

U.S. Department of Energy

Richland Operations Office

M. S. French

C. S. Louie

J. Zeisloft

Washington Closure Hanford

J. F. Armatrout

J. E. Blackburn

D. L. Boecker

R. A. Caulfield

G. L. Dover

B. E. Stubbs

Document Control
A3-04

A3-04

A3-04

T2-03

$\mathrm{H} 4-15$

T2-03

T2-07

$\mathrm{H} 4-24$

T2-03

H4-11 